\title{
Policy Formulation on Accelerating the Development of Electric Motor Vehicles
}

\author{
Siti Marwiyah, Vincensia Mutiara Rengganis* \\ Legal Science, Faculty of Law, Sebelas Maret University, Surakarta, Central Java, Indonesia \\ "Corresponding author. Email: mutiararengganis11@gmail.com
}

\begin{abstract}
The emergence of indonesian dependence on the use of fossil fuels in the form of petroleum as a transportation energy resource, has resulted in anincrease in the concentration of $\mathrm{CO}_{2}$ in the atmosphere. The Indonesian government then decided to switch to the use of renewable technology transportation that is more energy efficient and environmentally friendly. In this case, the Indonesian government launched a policy of regulationon the developmentof electric motor vehicles embodied in Presidential Regulation No. 55 of 2019 on Accelerating the Battery Electric Vehicle Program for Road Transportation. One form of supporting the Indonesian government against this policy is by providing incentives to the transportation industry. In order to succeed this policy, it requires support from all parties, both government and citizens so as to minimize the obstacles that may occur.
\end{abstract}

Keywords: Petroleum; Electric Motor Vehicle; Government support; Obstacles

\section{INTRODUCTION}

Petroleum is known as one of the natural resources that cannot be renewed so that over time, gradually the existence of petroleum will certainly decrease and even run out. Based on data obtained from the BP Statistical Review of World Energy (2016), Indonesia is recorded as the 24th largest petroleum producer in the world capable of producing 825,000-barrels of petroleum per day. No wonder if the use of petroleum as one of the fossil fuels in Indonesia reaches 50\% of the many energy need [5]. However, with the dependence of Indonesian people on the use of fossil fuels in the form of petroleum is certainly not a positive thing. This is because excessive use of fossil energy even if it continues to be used sustainably can increase the concentration of $\mathrm{CO}_{2}$ in the atmosphere so that it will be bad for environmental balance.

The increase in atmospheric $\mathrm{CO}_{2}$ concentrations is evidenced by data stating that in 2015 the concentration of $\mathrm{CO}_{2}$ in the atmosphere increased to $400.26 \mathrm{ppm}$ (Abas, et al., 2015). Then, according to the observatory, Mauna Loa, that the level of $\mathrm{CO}_{2}$ in the atmosphere reached $415.39 \mathrm{ppm}$ in 2019. Then in 2013, the transportation sector became one of the sectors that spend energy resources as much as $27.6 \%$ of which $92.6 \%$ is based on the consumption pattern of petroleum products. With the amount of energy spent in the transportation sector, of course we can imagine how much $\mathrm{CO}_{2}$ emissions are also produced, which is $22.9 \%$ of the total carbon dioxide emissions in the world (Woo et al., 2017). Seeing a significant amount of urgency, the Indonesian government along with the competent stakeholders decided to switch from the conventional fossil fuel transportation sector in the direction of transportation with the newest knology that is energy efficient and certainly environmentally friendly.

One of the real responses from the Indonesian government in responding to public problems is to certify the policy of developing electric motor vehicles as outlined in Presidential Regulation No. 55 of 2019 on Accelerating Battery Electric Vehicle Program for Road Transportation. Furthermore, quoted from the news page resmi cnnindonesia.com (2021) Indonesian President Joko Widodo openly stated that he wants Indonesia to be the "King of Batteries" to electric cars. world. From the data obtained, President Joko Widodo hopes that nickel mines scattered throughout the archipelago can be used as raw materials for battery makers for electric motor vehicles or energy-base vehicles. Electric cars such as the existence of electric cars in developed countries (Fea, 
2021). Not only bualan alone, Presidential Regulation No. 55 of 2019 actually received support and positive response from various stakeholders, including the Ministry of Industry. Where in 2020 the Ministry of Industry again clarifies Presidential Regulation No. 55 of 2019 which is in place with The Minister of Industry Regulation No. 27 of 2020 and Regulation of the Minister of Industry No. 28 In 2020 as well as Governor Regulation No. 3 of 2020 on Duty Incentives Behind the Name of Motorized Vehicles on Battery-Based Motor Vehicles.

This policy of electric motor vehicle development certainly needs good cooperation from various parties, which in this case means not only the government plays a role but all stakeholders related to even civil society. Basically, policies arise when there is an urgency or public problem that is significant enough and has implications for several sectors of life. With the projection of existing public problems, later the published policies will be more on target and have positive implications for the order of life in a country.

Deep thing this with there is Various Support from the government together stakeholders that Authorized Other policy development Electric motor vehicles are not a good thing. It is impossible to implement in Indonesia. With its current status as a developing country. Alpun such challenge and Obstacles from implemented one policy certainly not get released. Article this discuss about how existence policy developmentElectric motor vehicles in terms of urgency In the community, supportn whatever is given by government to succeed this policy, and what are the inhibitory factors Only that can be found at time forthcoming when policy this continue Implemented.

\section{METHOD OF WRITING}

Data and information that supports the writing of this article are obtained by conducting various library study searches and searches on sources.

Relevant source of information. Data and information collection techniques are carried out as follows:

1. Collect data and information by conducting various literature studies, both from journals, thesis, and other relevant sources from the internet.

2. Using some or all of the data and information obtained, then used as consideration and additional insights for the author.

The data and information obtained are reprocessed by applying descriptive analysis methods. According to Sugiyono (2014:21) "descriptive analysis methods are statistics that are used to analyze data in a wayto describe or describe data that has been collected as is without intending to make conclusions that apply to the public.

\section{DISCUSSION}

\subsection{Electric Motor Vehicle Development Policy}

Based on data from the Press Release of the National Development Planning Agency or BAPEPENAS (2017), Indonesia in the range of 2030-2040 is predicted to experience demographic bonuses or can be interpreted as a condition when the amount of the productive age will be greater than the population of unproductive age. In that year's range, the number of productive age population in Indonesia will reach $64 \% \mathrm{f}$ the total population that has been projected by BAPPENAS as many as 297,000,000. Soul (BAPPENAS, 2017). Reflecting on this, it should be noted that as the population increases in a country, the intensity of energy resource needs, especially transportation, will also continue to grow overtime. One of the government's real responses to the existence of the empirical-objective phenomenon is the issuance of Presidential Regulation No. 55 of 2019 on Accelerating battery-based electric motor vehicle programs (Battery Electric Vehicle) For Road Transportation. The Ministry of Industry of the Republic of Indonesia also confirmed the policy of the development of electric motor vehicles embodied in Presidential Regulation No. 55 of 2019 concerning Acceleration of Battery-Based Electric Motor Vehicle Program, which Taufiek Bawazier as Director General of ILMATE ministry of Industry of the Republic of Indonesia stated that the Indonesian government has targeted 400,000 units of cars Electricity and 1,760,000 units of motorcycles in 2025 [3]. The urgency of the procurement of electric motor vehicle units is to support.

The achievement of targets from the Indonesian government and the Indonesian Ministry of Industry can reduce the number of greenhouse gas emissions or GHGs by $29 \%$ by 2030 [3]. This goes hand in hand with the dynamics of the development of the times that also move towards the us of energy-efficient and more environmentally friendly transportation.

As a form of support for the government's efforts to realize the policy of developing electric motor vehicles, the Ministry of Industry of the Republic of Indonesia also published other policies to clarify and detail existing policies. through the Regulation of the Minister of Industry No. 27 of 2020 on Specifications, Roadmap of Development, and Provisions of Calculating the Value of Domestic Component Level of Battery-Based Electric Motor Vehicles (BEV) and Regulations Minister of Industry No. 28 of 2020 on Battery-Based Electric Motor Vehicles in a Complete Decomposed State (CKD) and Incomplete Undegradable Conditions.

The existence of an electric motor vehicle development policy deserves a positive response from various parties. Because until now Indonesia still relies on the use of fossil energy which reaches $95 \%$ and as 
much as $50 \%$ is sourced from petroleum [5].

This is certainly not a small amount, considering that excessive use of fossil energy even if continued to be used sustainably can increase the concentration of $\mathrm{CO}_{2}$ in the atmosphere.

\subsection{Government Support for Electric Motor Vehicle Rolling}

The existence of electric motor vehicles that have recently been widely discussed is a solution that can be done to reduce the use of motor vehicles with fossil fuels which can increase the concentration of $\mathrm{CO}_{2}$ in the atmosphere. Based on the data obtained, this electric motor vehicle has a variety of advantages that should be used as more value for consideration materials related to it susefulness in the future. One of the advantages of electric motor vehicles is the absence of exhaust gases so that it will not contribute significantly to the rate of global warming or carbon footprint in Indonesia [6].

Seeing the very positive implications of the existence of electric motor vehicles, finally the Indonesian government provides various support as outlined through Presidential Regulation No. 55 of 2019 regarding the Acceleration of Battery-Based Electric Motor Vehicle Program (Battery Electric Vehicle) For Road Transportation which states that the government is ready to pour incentives to the transportation industry to accelerate transportation development efforts, especially in electric motor vehicles.

Indonesian government support to accelerate the development of electric motor vehicles through the provision of incentives to the transportation industry as stated in Presidential Regulation No. 55 of 2019, among others. Other:

1. The provision of import duty incentives from electric motor vehicles that can also be called completely knock down (CKD) or incompletely knock down (IKD), which in this case is the main component related to capacity or the amount and time period specified.

2. Procurement of fiscal incentives for the overall manufacturing process of equipment and unit equipment in charging electric vehicles in general (SPKLU) such as for export funding, research procurement and development, parking fee rates, electricity charging fee waivers in SPKLU and spklu development, as well as certification of competence for human resources of electric motor vehicles and certification of products and technical standards for a related electric motor vehicle industry.

3. Procurement of non-fiscal incentives in the form of exceptions related to restrictions on road use, the provision of production rights, and the construction of operational security in the related transportation industry sector.

Through the electric motor vehicle development policy listed in Presidential Regulation No. 55 of 2019, the government together with other authorized stakeholders are committed to continue to support the acceleration of the development of electric motor vehicles. As one form of transition of conventional transportation (fossil fuel) towards transportation with the latest technology to anticipate the addition of demand for fossil fuels, especially petroleum that is getting bigger in the future.

Another form of support from the Indonesian government in addition to the issue of Presidential Regulation No. 55 of 2019 is the also the enactment of The Minister of Industry Regulation No. 27 of 2020 and Regulation of the Minister of Industry No. 28. In 2020 and Governor Regulation No. 3 of 2020 on Duty Incentives Behind the Name of Motor Vehicles on Battery-Based Motor Vehicles.

\subsection{Inhibiting Factors of The Use of Electric Motor Vehicles}

As is known that the process of shifting conventional, fossil-fueled transportation towards electricity-based transportation requires support from all parties, not only the government and the authorities only. This is necessary to minimize obstacles and challenges that may occur as a result of the process of switching the use of electric motor vehicles as the main transportation. According to Aziz et al (2020) several inhibitory factors that may occur, among others [2]:

\section{Vehicle Price and Maintenance}

With various financing needs for the manufacture of overall equipment and unit equipment in the general charging of electric motor vehicles (SPKLU) to product certification, the price of electric motor vehicles until now It can be categorized as expensive. In addition, the reason why the price of an electric motor vehicle is fairly expensive is the time in charging a long battery (4 to 6 hours with a distance of $160 \mathrm{~km}$ ), the electric power available in the battery. Every resident's house is not necessarily sufficient, as well as the cost of taxing electric motor vehicles that are certainly not cheap.

2. Readiness of Supporting Infrastructure With many needs

What needs to be done to care for electric motor vehicles such as charging batteries with high enough electric power, until now Indonesia has not been able to complete all kinds of supporting infrastructure. In terms of readiness of supporting infrastructure this can be a lack of electric motor 
vehicle refueling places considering that not every house has high electric power.

3. Universal Standards and Regulations regarding Electrical Facilities

Until now Indonesia is still included in the category of developing newhich has a fairly high level of dependence with other countries. This condition is also an obstacle for Indonesia in meeting the standards of utility of electricity sources and electricity facilities.

4. Performance of Electric Motor Vehicles with the Standard of Living Needs of Indonesian People.

As explained in the first point, this electric motor vehicle requires sufficient maintenance in some remote areas in Indonesia. This is related to the need for electrical power for battery charging that is fairly high. So it can be predicted that the existence of electric motor vehicles can only be used in large cities only. In addition, judging from the completeness of electric motor vehicles, which in this case is an electric car with a capacity of two passengers was not enough to meet the standard of living of the people of Indonesia who mostly buy cars to function as cars family.

\section{CONCLUSION AND SUGGESTION}

\subsection{Conclusion}

Based on the above discussion, that the government's policy in the framework of the development of electric motor vehicles has been realized through Presidential Regulation No. 55 of 2019 on Accelerating the Battery Electric Vehicle Program for Road Transportation. The Indonesian government has also targeted the procurement of electric motor vehicle units in the form of electric cars and electric motors for 2025. The urgency of the procurement of electric motor vehicles is to support the achievement of the Indonesian government's targets and increase greenhouse gas (GHG) emissions figures.

The Indonesian government's support for the policy of accelerating the development of electric motor vehicles is realized through the provision of incentives to the transportation industry as stated in Presidential Regulation No. 55. 2019. In addition, other government support is realized in the Regulation of the Minister of Industry No. 27 of 2020 and Regulation of the Minister of Industry No. 28 of 2020 and Governor Regulation No. 3 of 2020 on Duty Incentives behind The Name of Motor Vehicles on Battery-Based Motor Vehicles. However, there are several inhibitory factors that can affect the implementation of the policy, both in terms of price and vehicle maintenance, readiness of supporting infrastructure, standards. Universal and regulations related to electrical facilities, as well as in terms of performance of electric motor vehicles with standards the living needs of the People of Indonesia.

\subsection{Suggestion}

The author provides advice to the parties concerned in this case is the Government of Indonesia and all citizens of the community to jointly respond positively and support government policies related to accelerating the development of electric motor vehicles in order to minimize obstacles that may occur. The Government of Indonesia must also consider and think carefully about the solutions that can be taken to minimize the obstacles that occur so that this policy can later be implemented to the maximum and the purpose of the implementation of this policy can be achieved.

\section{REFERENCES}

[1] T. Afandi, Demographic Bonus 2030-2040: Indonesia's Strategy related to Employment and Education, in a Press Release of the Ministry of VAT / BAPPENAS, May 22, 2017.

[2] M. Aziz, M. Joshua, A. R. Intan, A. I. Sri, and W. S. Joni, Study Analysis of Technological Developments and Support of the Indonesian Government Related to Electric Cars. LA TEST: Journal of Electrical Engineering, 22(1), 2020, 4555

[3] Ministry of Industry, Government Efforts on The Growth of The Electric Vehicle Industry, in the Ministry of Industry News, February 22, 2021

[4] D. R. Son, Y. Donny, and T. Suyono, Electric Energy-Based Energy Security Policy in the Field of Transportation to Support State Defense in Indonesia: A Conceptual Framework. NUSANTARA: Journal of Social Sciences, 7(3), 2020, 658-672

[5] M. A. Rahman, Making Electric Cars for Environmentally Friendly Transportation Solutions (Baskara Cars). Journal of Regional Research, 12(2), 2013, 1819-1837.

[6] B. P. Resosudarmo, D. A. Nurdianto, A. A. Yusuf, and B. P. Resosudarmo, Greenhouse Gas Emission in Indonesia: The Significance of Fossil Fuel Combustion. Regional Development, Energy and the Environment in Indonesia, Palembang: Indonesian Regional Science, 2009

[7] Sidabutar, T. P. Victor, Study of Electric Vehicle Development in Indonesia: Prospects and Obstacles. Journal of Economic Paradigms, 15(1), 2020, 21-38. 